\title{
Changes in recipient body mass index for the first year after kidney transplantation are associated with intrapatient variability of tacrolimus concentration and long-term graft function
}

\author{
Hyunmin Ko, Chris Tae Young Chung, Hyo Kee Kim, Kwang Woo Choi, Ahram Han, Jongwon Ha, Sangil Min
}

Department of Surgery, Seoul National University Hospital, Seoul, Korea

Background: The aim of this study was to investigate the 5-year outcome of kidney transplant recipient according to the weight changes for the first year after kidney transplantation.

Methods: Data were retrospectively collected for 289 kidney transplant recipients between January 2012 and December 2014 in Seoul National University Hospital. Body mass index (BMI) was assessed at pre-transplant and before discharge, 1-month, 3-month, 6-month, and 12-month post-transplant. Intrapatient variability (IPV) was calculated as a coefficient of variation (CV), and outcome was evaluated as graft survival, estimated glomerular filtration rate (eGFR), and viral infection. The two groups according to the BMI changes during 1 year were divided as follows: group I (BMI change $\leq-1.5 \mathrm{~kg} / \mathrm{m}^{2}$ or $\geq+1.5 \mathrm{~kg} / \mathrm{m}^{2}$ ) and group II $\left(-1.5 \mathrm{~kg} / \mathrm{m}^{2}<\right.$ BMl change $\left.<+1.5 \mathrm{~kg} / \mathrm{m}^{2}\right)$.

Results: BMI declined to its lowest level at discharge $\left(21.04 \pm 3.59 \mathrm{~kg} / \mathrm{m}^{2}\right)$ and gradually increased to one year $\left(22.38 \pm 3.18 \mathrm{~kg} / \mathrm{m}^{2}\right)$. There was no significant correlation between IPV and $B M I$ change $(r h o=0.19, P=0.757)$. However, the proportion of patients with high IPV $(C V>25 \%)$ was higher in group I $(P=0.008)$. There was no difference in graft survival between the two groups $(P=0.646)$. The amount of change in eGFR (5-year eGFR to 1-year eGFR) tended to decrease to $-3.29 \pm 25.65 \mathrm{~mL} / \mathrm{min} / 1.73 \mathrm{~m}{ }^{2}(P=0.185)$ in group I, whereas it tended to slightly increase to $0.78 \pm 18.38 \mathrm{~mL} / \mathrm{min} / 1.73 \mathrm{~m}^{2}(\mathrm{P}=0.583)$ in group II. However, there was no statistically significant difference between the two groups $(P=0.154)$. There was no significant difference between the two groups in the incidence of viral infection (any virus, $\mathrm{P}=0.928$; cytomegalovirus, $\mathrm{P}=0.830$ ).

Conclusions: Our data demonstrated that recipients were more likely to have high IPV when the change in BMI was greater than $\pm 1.5 \mathrm{~kg} / \mathrm{m}^{2}$ during 1 year after kidney transplantation. In addition, there was a tendency for the 5 -year eGFR to decrease in those patients. 